\title{
Kadar N-Terminal Pro-Brain Natriuretic Peptide sebagai Prediktor Luaran Klinis Sindrom Koroner Akut
}

\author{
Florencia Idajanti Tandhana, ${ }^{1}$ Noormartany, ${ }^{2}$ Toni M. Aprami, ${ }^{3}$ Nina Tristina ${ }^{4}$ \\ ${ }^{1}$ Rumah Sakit Umum Daerah Subang, ${ }^{2}$ Bagian Ilmu Penyakit Dalam Fakultas Kedokteran \\ Universitas Padjadjaran-Rumah Sakit Dr. Hasan Sadikin Bandung
}

\begin{abstract}
Abstrak
Kadar N-terminal pro-brain natriuretic peptide (NT-proBNP) plasma dapat menggambarkan tingkat keparahan iskemia walaupun tidak terjadi nekrosis, iskemia yang transien dapat meningkatkan peregangan dinding jantung yang akan menginduksi sintesis dan pelepasan brain natriuretic peptide (BNP) yang sebanding dengan tingkat keparahan iskemia. Tujuan penelitian untuk mengetahui apakah kadar NT-proBNP pada penderita sindrom koroner akut (SKA) dapat digunakan sebagai parameter prediktor luaran klinis. Penelitian dilakukan sejak bulan Januari hingga Maret 2010. Subjek penelitian penderita SKA yang datang ke Unit Gawat Darurat Rumah Sakit Dr. Hasan Sadikin Bandung dan telah didiagnosis klinis sesuai kriteria World Health Organization. Pada subjek yang memenuhi kriteria inklusi dilakukan pemeriksaan kadar NT-pro BNP dengan metode electrochemiluminescence immunoassay, cardiac troponin $T$ (kuantitatif), dan creatine kinase muscle brain (enzimatik). Analisis data uji normalitas menggunakan one-sample Kolmogorov-Smirnov test, analisis regresi logistik multipel untuk mengetahui parameter prediktor luaran klinis penderita SKA. Dari 83 subjek yang ikut dalam penelitian, didapatkan nilai prediksi kadar NT-proBNP sebesar 1,00 sehingga bukan merupakan prediktor utama luaran klinis, koefisien $\beta$ NTproBNP sebesar 0,001 menyatakan bahwa setiap penambahan $1.000 \mathrm{pg} / \mathrm{mL}$ variabel NT-proBNP akan menambah lama perawatan 1 hari. Pada subjek SKA dengan luaran (outcome) sembuh nilai prediksi cTnT lebih baik sebagai faktor prediktor dibandingkan dengan konsentrasi NT-proBNP $(\mathrm{OR}=32,53 ; 95 \% \mathrm{IK} ; 0,58-1.819,26)$. Simpulan, NT-proBNP bukan merupakan prediktor utama luaran klinis pada SKA. Kadar NT-proBNP lebih dari 826,7 pg/mL terdapat kemungkinan prognosis yang buruk sampai dengan kematian. [MKB. 2012;44(2):106-13].
\end{abstract}

Kata kunci: Lama rawat, luaran klinis, $N$-terminal pro-brain natriuretic peptide (NT-proBNP), prediktor

\section{The Role of NT-proBNP as Clinical Outcome Predictor for Acute Coronary Syndromes}

\begin{abstract}
Plasma levels of N-terminal pro-brain natriuretic peptide (NT-proBNP) levels may reflect the severity of ischemia, although there is no necrosis. A transient ischemia which can increase the heart wall stretch would induces BNP synthesis and release. Synthesis and release of BNP are comparable with the severity of ischemia. The aim of this study was to analyze whether NT-proBNP levels in patients with acute coronary syndrome (ACS) can be used as a predictor for clinical outcome. Studies was held since January to March 2010. Subject were patients with ACS who came to emergency room Dr. Hasan Sadikin Hospital Bandung and were clinically diagnosed according to World Health Organization criteria. Subjects which were suited with the inclusion criteria, stored until assayed. NT-pro BNP concentration was examined by electrochemiluminescence immunoassay method along with creatine kinase muscle brain (enzymatic method) and cardiac troponin T (quantitative method). Statistical analysis was performed using the one-sample Kolmogorov-Smirnov test for verifying normality, normally distributed data were analyzed using parametric analysis and abnormal distributed data was assayed using multiple logistic regression analysis to determine the parameters which can be used as predictor for clinical outcome in patients with ACS. Multiple logistic regression analysis on 83 subjects showed predictive value of NT-proBNP levels with $\mathrm{OR}=1.00$, which mean there was no different likelihood in patients with high and low concentration of NT-proBNP to have longer hospitality duration. NT-proBNP $\beta$ coefficient of 0.001 states that every addition of $1,000 \mathrm{pg} / \mathrm{mL}$ of NT-proBNP concentration will increase the length of hospitality duration for one day. On convalesce subjects, the most significant predictive value for predicting clinical outcome cTnT was more better than NT-proBNP concentration in patients with ACS $(\mathrm{OR}=32.53,95 \% \mathrm{CI} ; 0.58-1,819.26)$. In conclusions, NT-proBNP is not a major predictor of clinical outcome in ACS. NT-proBNP levels of $>826.7 \mathrm{pg} / \mathrm{mL}$ implies a poor prognosis to death. [MKB. 2012;44(2):106-13].
\end{abstract}

Key words: Long hospitality, N-Terminal pro-brain natriuretic peptide (NT-proBNP), outcome, predictor

Korespondensi: Florencia Idajanti Tandhana, dr., Sp.PK, Rumah Sakit Umum Daerah Subang, jalan Brigjen Katamso 37 Subang, telepon (0260) 411421, faks (0260) 421031, mobile 08156123517, e-mail idajanti37@yahoo.co.id 


\section{Pendahuluan}

Morbiditas dan mortalitas sindrom koroner akut (SKA) baik di negara maju maupun di negara berkembang meningkat bermakna. Pada tahun 1996 The Health Survey for England menyatakan bahwa 1,4 juta penduduk dewasa menderita angina dan 246.000 orang penduduk dewasa mengalami infark miokardium dalam 12 bulan terakhir. Penyakit jantung koroner merupakan penyebab sekitar 3\% perawatan rumah sakit yaitu 284.292 perawatan dengan masa rawat sekitar tujuh hari. ${ }^{1-4}$

Sindrom koroner akut merupakan kumpulan kelainan ataupun gejala jantung dan gambaran elektrokardiogram berupa angina pektoris tidak stabil (unstable angina pectoris/UAP), infark miokardium akut (IMA) baik dengan peningkatan segmen ST (ST segmen elevation myocardial infarction/STEMI) maupun tanpa peningkatan segmen ST (non ST segmen elevation myocardial infarction/NSTEMI). ${ }^{5,6}$

Patofisiologi yang mendasari SKA biasanya ruptur plak akut dengan berbagai macam tingkatan sumbatan pembuluh darah. Meskipun patofisiologi sama, namun diagnosis, strategi penatalaksanaan, hasil terapi, dan stratifikasi risiko masing-masing penderita berbeda. Diagnosis akurat dan stratifikasi risiko penderita SKA merupakan masalah yang sangat penting, agar dapat diberikan terapi yang optimal..$^{-9}$

Sensitivitas elektrokardiografi (EKG) dalam mendeteksi SKA rendah yaitu $\pm 50 \%$, sedangkan spesifisitasnya hanya $40 \%$. Enzim jantung creatine kinase (CK) dan creatine kinase muscle brain (CKMB) dapat memberikan informasi diagnostik yang lebih akurat, tetapi keduanya memiliki nilai prognostik yang terbatas. Cardiac troponin $T$ (cTnT) mempunyai sensitivitas $97 \%$ dan spesifisitas 99\% untuk mendeteksi kerusakan sel otot jantung yang ireversibel sehingga troponin dapat digunakan untuk diagnosis pada SKA, tetapi kadarnya akan tetap tinggi selama satu minggu setelah infark miokardium. Hal ini menyebabkan kemampuan untuk dapat mendiagnosis episode re-infark minor terbatas. ${ }^{8}$

Sejak beberapa tahun terakhir telah mampu dikembangkan pemeriksaan laboratorium kelompok neurohormon natriuretic peptide (NP), khususnya brain natriuretic peptide (BNP) yang terbukti merupakan suatu penanda biokimiawi jantung yang sangat berguna untuk prognosis SKA. Brain natriuretic peptide merupakan salah satu kelompok natriuretic peptide yang disintesis oleh miosit dan dilepaskan pada waktu terjadi stres hemodinamik seperti pada waktu terjadi dilatasi dan hipertrofi ventrikel atau terjadi peningkatan tekanan terhadap dinding jantung. Selain itu, BNP juga menyebabkan vasodilatasi, diuresis, natriuresis, serta menurunkan sistem renin-angiotensin-aldosteron dan sistem saraf simpatetik. Brain natriuretic peptide (BNP) disintesis sebagai prohormon yang disebut proBNP. Setelah stimulasi regangan miokardium maka proBNP dipecah oleh protease menjadi $N$-terminal pro-brain natriuretic peptide (NT-proBNP) dan hormon aktif BNP. Kedua peptida tersebut dilepaskan ke dalam sirkulasi. Waktu paruh biologis NT-proBNP yaitu 60-120 menit lebih stabil dibandingkan dengan BNP yaitu 20 menit. Beberapa penelitian menunjukkan bahwa selain merupakan indikator mortalitas jangka panjang yang cukup baik pada penderita SKA juga dapat digunakan untuk menilai prognosis SKA di samping penanda biokimiawi lain, seperti cTnT dan CKMB. ${ }^{10,11}$

Kadar BNP dapat menggambarkan tingkat keparahan iskemia walaupun tidak terjadi nekrosis dan hal ini didukung oleh beberapa penelitian yang menunjukkan bahwa iskemia yang bersifat sementara dapat meningkatkan peregangan dinding jantung serta menginduksi sintesis dan pelepasan BNP yang sebanding dengan tingkat keparahan iskemia. Peningkatan kadar NT-proBNP pada penderita SKA dapat menandakan peningkatan risiko gagal jantung atau risiko kematian baik jangka pendek (30 hari) maupun jangka panjang (satu tahun) dan meningkatkan lama perawatan, sehingga kadarnya dapat dijadikan prediktor luaran klinis (clinical outcome) (sembuh, meninggal, perawatan yang menjadi lama) pada penderita SKA. ${ }^{10-12}$

Standar operasional pelayanan lama perawatan rata-rata di Rumah Sakit Dr. Hasan Sadikin (RSHS) Bandung saat ini tujuh hari untuk penderita SKA tanpa komplikasi. Bila terdapat komplikasi lain seperti komplikasi mekanik (mitral komplikasi elektrik regurgitasi, ruptur septum), aritmia sampai gagal jantung ataupun infeksi nosokomial, maka lama perawatan dapat lebih panjang. ${ }^{13}$ Tujuan penelitian untuk mengetahui apakah kadar NTproBNP pada penderita SKA dapat digunakan sebagai parameter prediktor luaran klinis.

\section{Metode}

Penelitian dilakukan pada penderita SKA yang datang ke Unit Gawat Darurat (UGD) RSHS Bandung dan telah didiagnosis klinis sesuai kriteria World Health Organization (WHO). Kriteria inklusi penderita SKA dewasa, penderita SKA yang memenuhi dua dari tiga kriteria WHO: keluhan nyeri dada, kelainan EKG dan kenaikan enzim jantung (CKMB metode enzimatik)/penanda biokimia cTnT (cTnT kuantitatif) positif, penderita SKA yang datang ke UGD dan dirawat inap. Pada subjek yang memenuhi kriteria inklusi dilakukan pemeriksaan kadar NT-pro BNP serum dengan metode enzyme-chemiluminescense immunoassay 
(ECLIA), cardiac troponin $\mathrm{T}$ (cTnT), dan creatine kinase MB (CKMB).

Bentuk penelitian adalah observasional analitik dengan rancangan potong lintang. Dalam penelitian ini dilakukan pemeriksaan kadar NT-proBNP sebagai prediktor luaran klinis pada penderita SKA. Analisis statistik sesuai tujuan penelitian dan hipotesis, yaitu untuk mengetahui kadar NTproBNP sebagai prediktor luaran klinis pada penderita SKA. Analisis statistik dimulai dengan uji normalitas menggunakan one-sample KolmogorovSmirnov test with Lilliefors significance correction untuk menguji apakah data berdistribusi normal atau tidak. Bila data berdistribusi normal digunakan analisis parametrik, sedangkan bila data tidak berdistribusi normal dicoba dilakukan transformasi data agar tetap menggunakan analisis parametrik. Lama perawatan (variabel dependen) dikategorikan sebagai $\leq 7$ hari dan $>7$ hari. Analisis regresi logistik berganda (multiple logistic regression) ${ }^{6,9}$ dilakukan dengan lama perawatan sebagai variabel dependen atau luaran klinis, kadar NT-proBNP sebagai variabel independen utama, variabel perancu yaitu usia, jenis kelamin, luas kerusakan otot jantung, riwayat dekompensasi jantung. Data yang telah dikumpulkan diolah dengan program SPSS versi 15.0 untuk Windows dengan kemaknaan hasil uji statistik ditentukan pada nilai $\mathrm{p}<0,05$.

\section{Hasil}

Karakteristik subjek penelitian berdasarkan usia, jenis kelamin, CKMB, cTnT, komplikasi, kadar NT-proBNP dan lama perawatan dapat terlihat bahwa usia rata-rata (SD) subjek penelitian ini 56 tahun, dengan usia paling muda 26 tahun dan paling tua 86 tahun dengan subjek penelitian paling banyak laki-laki yaitu sebanyak 59 orang (71\%). Hasil penelitian menunjukkan sebagian besar subjek penelitian memiliki kadar CKMB abnormal (kadarnya $>25 \mathrm{U} / \mathrm{L}$ ) yaitu sebanyak 76 orang (92\%). Sebagian besar subjek penelitian memiliki hasil cTnT positif yaitu sebanyak 39 orang (47\%)

Tabel 1 Karakteristik Subjek Penelitian berdasarkan Usia, Jenis Kelamin, CKMB, cTnT, Komplikasi, Kadar NT-proBNP, dan Lama perawatan

\begin{tabular}{|c|c|}
\hline Variabel $(n=83)$ & Nilai Statistik \\
\hline \multicolumn{2}{|l|}{ Usia (tahun) } \\
\hline Rata-rata (SB) & $56(11,9)$ \\
\hline \multicolumn{2}{|l|}{ Jenis kelamin (n, \%) } \\
\hline Laki-laki & $59(71 \%)$ \\
\hline Perempuan & $24(29 \%)$ \\
\hline \multicolumn{2}{|l|}{ CKMB (n, \%) } \\
\hline Abnormal (>25 U/L) & $76(92 \%)$ \\
\hline Normal $(<25 \mathrm{U} / \mathrm{L})$ & $7(8 \%)$ \\
\hline \multicolumn{2}{|l|}{ cTnT (n; \%) } \\
\hline Positif & $39(47 \%)$ \\
\hline Negatif & $44(53 \%)$ \\
\hline \multicolumn{2}{|l|}{ Komplikasi (n, \%) } \\
\hline Ya & $4(5 \%)$ \\
\hline Tidak & $79(95 \%)$ \\
\hline \multicolumn{2}{|l|}{ Kadar NT-proBNP (pg/mL) } \\
\hline Median (Rentang) & $1.088(21,46->35.000)$ \\
\hline \multicolumn{2}{|c|}{ Lama perawatan (quintil)(hari) (n, \%) } \\
\hline Median (Rentang)(hari) & $5(1-16)$ \\
\hline$<3$ & $10(12 \%)$ \\
\hline $3-5$ & $33(40 \%)$ \\
\hline$>5-6$ & $13(16 \%)$ \\
\hline$>6-9$ & $11(13 \%)$ \\
\hline$>9$ & $16(19 \%)$ \\
\hline \multicolumn{2}{|c|}{ Lama perawatan (kategorik)(hari) (n, \%) } \\
\hline$>7$ & $22(26 \%)$ \\
\hline$\leq 7$ & $61(74 \%)$ \\
\hline
\end{tabular}


Florencia: Kadar N-Terminal Pro-Brain Natriuretic Peptide sebagai Prediktor Luaran Klinis Sindrom Koroner Akut

Tabel 2 Perbedaan Karakteristik Subjek dengan Luaran Meninggal dan Sembuh

\begin{tabular}{|c|c|c|c|}
\hline Variabel & Meninggal $(\mathrm{n}=9)$ & Hidup $(n=74)$ & $\mathbf{p}$ \\
\hline Usia & & & $0,793^{* * *}$ \\
\hline Median (Rentang) & $51(40-78)$ & $57(26-86)$ & \\
\hline Jenis kelamin & & & $\left.0,513^{*}\right)$ \\
\hline Laki-laki & 6 & 53 & \\
\hline Perempuan & 3 & 21 & \\
\hline СКМВ & & & $\left.0,182^{*}\right)$ \\
\hline Abnormal & 9 & 67 & \\
\hline Normal & 0 & 7 & \\
\hline Troponin $\mathrm{T}$ & & & $\left.0,681^{*}\right)$ \\
\hline Positif & 6 & 33 & \\
\hline Negatif & 3 & 41 & \\
\hline Komplikasi & & & $0,588^{*}$ \\
\hline Ya & 0 & 4 & \\
\hline Tidak & 9 & 70 & \\
\hline Kadar NT-proBNP & & & $0,003^{* * *}$ \\
\hline Median (Rentang) & $20.163(826,70->35.000)$ & $1.020,50(21,46->35.000)$ & \\
\hline Lama perawatan (quintil)(hari) & & & $0,556^{* *)}$ \\
\hline Median (Rentang) & $5(1-10)$ & $5(1-16)$ & \\
\hline$<3$ & 3 & 7 & \\
\hline $3-5$ & 2 & 31 & \\
\hline$>5-6$ & 1 & 12 & \\
\hline$>6-9$ & 2 & 9 & \\
\hline$>9$ & 1 & 15 & \\
\hline \multicolumn{4}{|l|}{ Lama perawatan (kategorik)(hari) } \\
\hline$>7$ & 2 & 20 & \\
\hline$\leq 7$ & 7 & 54 & \\
\hline
\end{tabular}

dan cTnT negatif sebanyak 44 orang (53\%); dan sebagian besar subjek penelitian yang tidak mengalami komplikasi sebanyak 79 orang $(95 \%)$ (Tabel 1).

Median kadar NT-proBNP subjek penelitian pada penelitian ini $1.088 \mathrm{pg} / \mathrm{mL}$ dengan kadar paling rendah $21,46 \mathrm{pg} / \mathrm{mL}$ dan kadar paling tinggi $>35.000 \mathrm{pg} / \mathrm{mL}$, sedangkan median lama perawatan subjek penelitian ini 5 hari dengan lama perawatan paling singkat satu hari dan paling lama 16 hari, dengan frekuensi tertinggi pada lama perawatan $\leq 7$ hari yaitu 61 (74\%) subjek (Tabel 1).

Subjek penelitian dengan luaran meninggal tidak terdapat hubungan bermakna usia, $\mathrm{CKMB}$, dan cTnT dengan lama perawatan pada penderita SKA $(95 \%$ IK, $\mathrm{p}>0,05)$. Hal ini dimungkinkan karena

Tabel 3 Hubungan Usia, CKMB, cTnT, dan Kadar NT-proBNP dengan Lama Perawatan berdasarkan Luaran Subjek Penelitian

\begin{tabular}{|c|c|c|c|c|}
\hline \multirow{3}{*}{ Variabel } & \multicolumn{4}{|c|}{ Lama Perawatan } \\
\hline & \multicolumn{2}{|c|}{$\begin{array}{c}\text { Meninggal } \\
(\mathrm{n}=9)\end{array}$} & \multicolumn{2}{|c|}{$\begin{array}{l}\text { Hidup } \\
(n=74)\end{array}$} \\
\hline & $\mathbf{r}$ & $\mathbf{p}$ & $\mathbf{r}$ & $\mathbf{p}$ \\
\hline Usia & 0,58 & 0,104 & 0,03 & 0,777 \\
\hline CKMB & $-0,54$ & 0,131 & $-0,13$ & 0,270 \\
\hline cTnT & $-0,21$ & 0,691 & 0,05 & 0,769 \\
\hline Kadar NT-proBNP & 0,72 & 0,030 & 0,34 & 0,003 \\
\hline
\end{tabular}




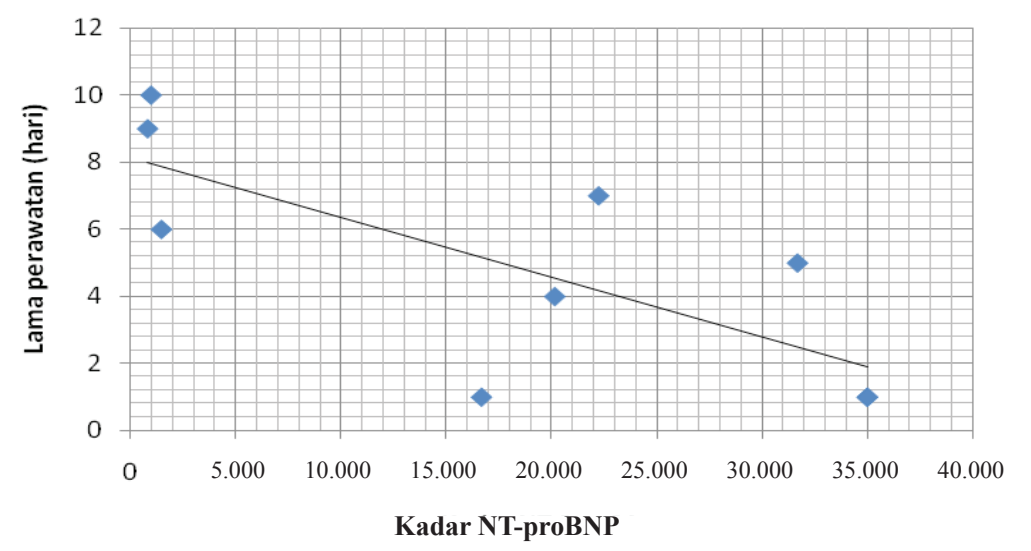

Gambar 1 Hubungan Kadar NT-proBNP dan Lama Perawatan dengan Luaran Meninggal

jumlah subjek penelitian yang meninggal sangat sedikit ( $\mathrm{n}=9$ ) (Tabel 2). Terdapat hubungan negatif antara kadar NT-proBNP dan lama perawatan yaitu semakin tinggi kadar NT-proBNP, maka semakin pendek lama perawatan karena penderita meninggal dunia $(95 \% \mathrm{IK}, \mathrm{p}=0,030 ; \mathrm{r}=0,72)$ yang menunjukkan hubungan yang kuat. Pada subjek dengan luaran sembuh terlihat hubungan positif antara kadar NT-proBNP dan lama perawatan yaitu semakin tinggi kadar NT-pro-BNP, maka semakin panjang lama perawatan sehingga penderita sembuh (95\% IK, $\mathrm{p}=0,003 ; \mathrm{r}=0,34)$ yang menunjukkan hubungan kekuatan sedang (Tabel 3).

Subjek penelitian dengan lama perawatan $\leq 7$ hari terlihat perbedaan kadar NT-proBNP dengan luaran meninggal dan hidup ( $95 \% \mathrm{IK}, \mathrm{p}<0,001)$. Tidak terdapat perbedaan karakteristik subjek penelitian berdasarkan usia, jenis kelamin, cTnT, dan komplikasi dengan luaran meninggal maupun hidup (95\% IK, $\mathrm{p}>0,05)$ (Tabel 2).

Subjek penelitian dengan luaran meninggal maupun hidup dengan lama perawatan $>7$ hari, tidak terdapat perbedaan kadar NT-proBNP, usia, jenis kelamin, cTnT, dan komplikasi $(95 \%$ IK, $\mathrm{p}=0,568$ ). Pada subjek dengan luaran meninggal, terdapat hubungan negatif antara kadar NT-proBNP dan lama perawatan yaitu semakin tinggi kadar NTproBNP, maka semakin pendek lama rawat karena penderita meninggal dunia (Gambar 1).

Setelah dilakukan pemodelan dengan multiple logistic regression test didapatkan nilai prediksi kadar NT-proBNP serum sebagai parameter yang digunakan untuk memperkirakan prediktor luaran klinis subjek penelitian luaran sembuh dengan nilai prediksi yang paling dominan yaitu $\mathrm{cTnT}$ dengan koefisien $\beta 3,482$ OR=32,53 (95\% IK; 0,58$1.819,26)$ (Tabel 4).

Persamaanregresilogistiktersebutmenunjukkan bahwa dari 83 subjek penelitian, berdasarkan analisis regresi logistik ganda didapatkan nilai prediksi kadar NT-proBNP OR=1,00 (95\% IK; 0,99-1,00) sehingga bukan merupakan prediktor utama luaran

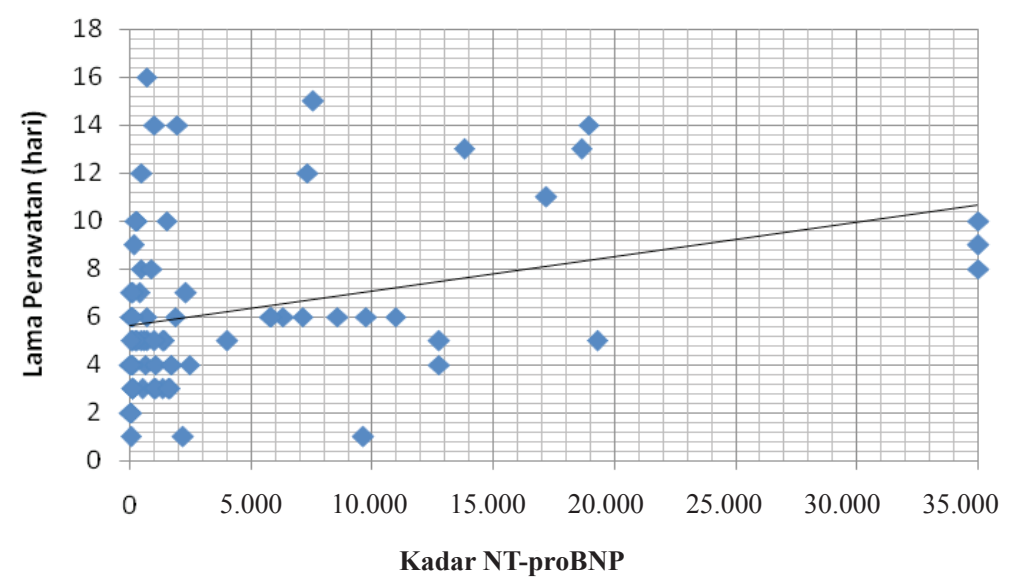

Gambar 2 Hubungan Kadar NT-proBNP dan Lama Perawatan Subjek Penelitian dengan Luaran Hidup 
Tabel 4 Nilai Prediksi Kadar NT-proBNP sebagai Parameter yang Digunakan untuk Memperkirakan Lama Perawatan pada Subjek Penelitian dengan Luaran Sembuh*

\begin{tabular}{llrcc}
\hline Model & \multicolumn{1}{c}{ Variabel } & Koefisen $\boldsymbol{\beta}$ & $\mathrm{p}$ & OR (95\% IK) \\
\hline Awal & Konstanta & 2,321 & 0,002 & \\
& NT-proBNP & 0,001 & 0,022 & $1,00(0,99-1,00)$ \\
& Usia & $-0,020$ & 0,686 & $0,98(0,89-1,08)$ \\
& Jenis kelamin & 1,323 & 0,411 & $3,75(0,16-87,88)$ \\
& CKMB & $-0,012$ & 0,056 & $0,99(0,98-1,00)$ \\
& cTnT & 3,445 & 0,109 & $31,35(0,46-2.117,58)$ \\
& Komplikasi & $-18,159$ & 0,109 & $0,00(0,00)$ \\
Akhir & 1,573 & $<0,001$ & \\
& Konstanta & 0,001 & 0,025 & $1,00(0,99-1,00)$ \\
& NT-proBNP & $-0,012$ & 0,053 & $0,99(0,98-1,00)$ \\
& CKMB & 3,482 & 0,090 & $32,53(0,58-1.819,26)$ \\
\hline
\end{tabular}

*Multiple logistic regression test

klinis. Koefisien $\beta$ NT-proBNP 0,001 menyatakan bahwa setiap penambahan $1.000 \mathrm{pg} / \mathrm{mL}$ variabel NT-proBNP akan menambah lama perawatan 1 hari. Pada subjek penelitian dengan luaran sembuh nilai prediksi cTnT lebih baik sebagai faktor prediktor dibandingkan dengan NT-proBNP dengan $\mathrm{OR}=32,53(95 \%$ IK; $0,58-1.819,26)$ (Tabel 4).

\section{Pembahasan}

Dari hasil penelitian didapatkan subjek SKA lakilaki lebih banyak dibandingkan dengan perempuan, yaitu 59 orang $(71 \%)$ sedangkan perempuan sebanyak 24 orang (29\%). Pada penelitian ini tidak didapatkan perbedaan bermakna antara luaran meninggal dan sembuh berdasarkan jenis kelamin (95\% IK, $p=0,513)$.

Hasil penelitian ini menunjukkan penderita lakilaki lebih banyak dibandingkan dengan perempuan kemungkinan karena perempuan dipengaruhi oleh hormon estrogen endogen yang bersifat protektif sehingga perempuan relatif lebih terlindungi dari penyakit jantung koroner sampai masa menopause, dan setelah itu menjadi sama rentannya seperti pria. Jenis kelamin juga tidak dapat memprediksi lama perawatan karena tidak ada hubungan sebab akibat, antara jenis kelamin dan lama perawatan..$^{14,15}$

Karakteristik subjek penelitian menurut usia menunjukkan bahwa usia rata-rata subjek penelitian ini 56 tahun, dengan usia termuda 26 tahun dan tertua 86 tahun. Pada penelitian ini tidak terdapat perbedaan bermakna antara lama perawatan $\leq 7$ hari $(95 \% \mathrm{IK}, \mathrm{p}=0,113)$; lama perawatan $>7$ hari $(95 \%$ $\mathrm{IK}, \mathrm{p}=0,059)$ dan luaran berdasarkan usia subjek penelitian ini dengan nilai $95 \% \mathrm{IK}, \mathrm{p}=0,793$.

Pada $76(92 \%)$ subjek penelitian didapatkan hasil CKMB abnormal (kadarnya $>25 \mathrm{U} / \mathrm{L}$ ). Hasil penelitian ini sesuai dengan teori yang menyatakan bahwa pada SKA terjadi peningkatan kadar CKMB serum yang merupakan indikator penting nekrosis miokardium. Hal ini juga sesuai dengan kriteria WHO bahwa pada penderita SKA terdapat peningkatan enzim jantung. ${ }^{9}$

Pada subjek didapatkan hasil pemeriksaan cTnT negatif sebanyak 44 orang (53\%), sedangkan pada subjek meninggal dengan lama perawatan $>7$ hari hasil cTnT lebih banyak positif yaitu 2 orang. Hasil penelitian ini sesuai degan teori yang menyatakan cTnT mempunyai sensitivitas $97 \%$ dan spesifisitas 99\% untuk deteksi kerusakan sel otot jantung yang ireversibel sehingga troponin dapat dipergunakan untuk diagnosis pada SKA, tetapi kadarnya akan tetap tinggi selama satu minggu setelah infark miokardium. Hal ini menyebabkan kemampuan cTnT untuk mendiagnosis episode re-infark minor terbatas. ${ }^{8-9}$ Hal tersebut menyebabkan tidak terdapat perbedaan bermakna berdasarkan luaran meninggal dan sembuh pada subjek penelitian $(95 \% \mathrm{IK}$, $\mathrm{p}=0,681$ ).

Hasil penelitian berdasarkan kadar NT-proBNP diperoleh median subjek penelitian ini $1.088 \mathrm{pg} /$ $\mathrm{mL}$. Berdasarkan hasil analisis Mann-Whitney antara kadar NT-proBNP dan luaran meninggal serta sembuh terdapat perbedaan bermakna $(95 \%$ IK, $p=0,003)$; sedangkan pada lama perawatan $\leq 7$ hari juga terdapat perbedaan bermakna $(95 \% \mathrm{IK}$, $\mathrm{p}<0,001$ ), namun pada lama perawatan $>7$ hari tidak terdapat perbedaan bermakna $(95 \% \mathrm{IK}, \mathrm{p}=0,568)$.

Kadar NT-proBNP serum berhubungan dengan mortalitas: dari data didapatkan bahwa meskipun dapat memprediksi kematian tetapi tidak selalu semakin tinggi kadar NT-proBNP maka mortalitas SKA makin tinggi. Hal ini disebabkan karena kematian pada SKAdipengaruhi oleh berbagai faktor seperti oklusi trombus, komplikasi mekanik (mitral komplikasi elektrik regurgitasi, ruptur septum), aritmia maupun infeksi nosokomial. Data penelitian 
ini menyatakan bila kadar NT-proBNP lebih dari $826,7 \mathrm{pg} / \mathrm{mL}$ maka tedapat kemungkinan prognosis yang buruk sampai dengan kematian karena pada subjek penelitian dengan luaran meninggal didapatkan kadar NT-proBNP terendah 826,7 pg/ $\mathrm{mL}$. Peningkatan kadar NT-proBNP pada subjek penelitian berhubungan dengan prognostik yang buruk dan kematian, selain itu juga untuk stratifikasi risiko dan prediktor iskemia miokardium. ${ }^{16}$

Berdasarkan analisis statistik $\mathrm{R}^{2}$ adjusted, maka untuk NT-proBNP didapatkan $\mathrm{R}^{2}$ 0,083; NT-proBNP hanya dapat menjelaskan atau memprediksi lama perawatan sebesar $8 \% ; 92 \%$ dijelaskan/ditentukan oleh faktor-faktor lain, dengan memperhitungkan pengaruh variabel independen lain (komplikasi, usia, jenis kelamin, cTnT, kadar CKMB).

Hasil penelitian menunjukkan bahwa dengan pemodelan multiple logistic regression test didapat nilai prediksi kadar cTnT koefisien $\beta 3,482$ (95\% IK, $\mathrm{p}<0,001 ; \mathrm{OR}=32,53)$. Hal ini menyatakan bahwa hasil cTnT mempunyai nilai prediktor yang tertinggi dibandingkan dengan NT-proBNP koefisien $\beta 0,001$ $(95 \% \mathrm{IK}, \mathrm{p}=0,025 ; \mathrm{OR}=1,00)$. Pemeriksaan $\mathrm{cTnT}$ akan rendah kadarnya/negatif $(<0,01 \mu \mathrm{g} / \mathrm{L})$ bila tidak terdapat nekrosis, hal ini menyebabkan cTnT tidak dapat digunakan sebagai prediktor tunggal luaran klinis maupun untuk melihat luaran hidup/ meninggal SKA. Hasil penelitian ini tidak sama dengan penelitian lain dimungkinkan karena yang terinklusi subjek penelitian ini telah terjadi nekrosis yang lama.

Pada 79 orang (95\%) subjek penelitian tidak mengalami komplikasi lain. Hal ini tidak terdapat perbedaan secara bermakna berdasarkan luaran meninggal dan sembuh $(95 \% \mathrm{IK}, \mathrm{p}=0,588)$. Hal ini disebabkan karena faktor-faktor yang dapat menyebabkan komplikasi sudah dieksklusi sejak pemilihan subjek penelitian (penderita gagal ginjal, penderita stroke, dan penderita yang dirujuk dari rumah sakit lain $>72$ jam sejak diagnosis SKA ditegakkan). Keterbatasan pada penelitian ini salah satunya penelitian ini tidak mempunyai data tentang ekokardiografi sebagai baku emas untuk mengetahui disfungsi ventrikular subjek penelitian. Disfungsi ventrikular menyebabkan gagal jantung yang akan meningkatkan kadar NT-proBNP. Keterbatasan lain penderita SKA tidak dikelompokkan berdasarkan NSTEMI, STEMI, dan UAP, sedangkan yang paling besar risikonya untuk mengalami gagal jantung yaitu STEMI. Keterbatasan lainnya dalam penelitian ini yaitu pemeriksaan NT-proBNP hanya dilakukan satu kali dan tidak dilakukan pemeriksaan ulangan pada hari ke-4 dan ke-7, sedangkan dengan pemeriksaan ulangan dapat dilihat trend pemeriksaan.

Simpulan, NT-proBNP bukan merupakan prediktor utama luaran klinis pada SKA, kadar NT-proBNP $>826,7 \mathrm{pg} / \mathrm{mL}$ terdapat kemungkinan prognosis yang buruk sampai dengan kematian.

\section{Daftar Pustaka}

1. American Heart Association: 2004 Heart and stroke statistical update. Dallas, Texas: American Heart Association; 2004.

2. World Health Organization Web site, Cardiovascular disease [diunduh 8 November 2009]. Tersedia dari: http://www.who.int/ncd/ cvd.

3. Budiarto RL, Sarimawar. Survei kesehatan rumah tangga. Pola kematian. Jakarta: Badan Lit-Bang Kes, Departemen Kesehatan Republik Indonesia; 1992.

4. Gray HH, Dawkins KD, Morgan JM, Simpson IA, penyunting. Penyakit jantung koroner. Lecture notes kardiologi. Edisi ke-4. Jakarta: Erlangga; 2005.

5. Felix J, Rogers DO. The clinical spectrum of acute coronary syndromes. JAOA. 2000;100 (11 supplement):1-7 .

6. Kleinschmidt KC. Epidemiology and pathophysiology acute coronary syndromes. Adv Stud Nurs. 2006;4(4):72-7.

7. Antman EM, Smith SC, Alpert JS, Anderson JL, Faxon DP, Fuster V, dkk. Guidelines for the management of patiens with ST-elevation myocardial infraction-executive summary a report of the American College of Cardiology/ American Heart Association task force on practice guidelines 2004. Circulation. 2004;110:588-636.

8. Roberts R, Fromm R. Management of acute coronary syndromes based on risk stratification by biochemical markers an idea whose time has come. Circulation. 1998;98:1831-3.

9. Maynard SJ, Scott GO, Riddell JW, Adgey AJ. Management of acute coronary syndromes. BMJ. 2000;321:220-3.

10. Adams KF, Lindenfeld J. HFSA 2006 comprehensive heart failure practice guideline. J Cardiac Failure. 2006;12:el-122.

11. Cowie MR, Jourdain P, Maisel A, Dahlstrom U, Follath F, Isnand R, dkk. Clinical application of B-type natriuretic peptide (BNP) testing. Eur J Heart Fail. 2003;24(19):1710-8.

12. Antman EM, Braunwald E. Acute myocardial infraction. Dalam: Braunwald E, penyunting. Heart disease, a textbook of cardiovascular medicine. Edisi ke-6. Philadelphia: WB Saunders; 2001. hlm. 1114-60.

13. Braunwald E, Antman EM, Beasley JW, Califf RM, Cheitlin MD, Hochman JS, dkk. Guideline update for the management of patients with unstable angina and non-ST-segment elevation myocardial infraction: a report of the American 
College of Cardiology/American Heart Association Task force on practice guidelines. J Am Coll Cardiol. 2002;40:1366-74.

14. Blankerberg S. Glutathion peroxidase1 activity and cardiovascular events in patients with coronary artery disease. $\mathrm{N}$ Engl $\mathrm{J}$ Med. 2003;349:1605-13.

15. Bertrand ME, Simoons ML, Fox KAA,
Wallentin LC, Hamm CW, McFadden E, dkk. Management of acute coronary syndrome in patients without persintent ST-segment elevation. Eur Heart J. 2002;23:1809-40.

16. Weber M, Hamm C. Role of B-type natriuretic peptide (BNP) and NT-pro BNPin clinical routine. Heart. 2006;92(6):843-9. 